\title{
Dødelighet, letalitet eller mortalitet?
}

\author{
Dødelighet har fra gammelt av vært benyttet som et mål på befolkningens helse. Men dødelighet er også et \\ mål på alvorligheten av dødelige sykdommer. De to faguttrykkene mortalitet og letalitet er begge avledninger \\ av ordet dødelighet. På mange måter gir de en mer presis betydning av begrepet.
}

Mortalitet uttrykker hvor stor del av en befolkning som dør i løpet av en tidsperiode (ramme 1). Man kan gjerne kalle det for insidensen av tilstanden død (1). Den beregnes ofte for hver enkelt sykdom (sykdomsspesifikk mortalitet) og angis da som regel som antall døde av den aktuelle sykdommen per 10000 , ev. opp til 100000 innbyggere per år. I nevneren inngår alle som kan tenkes å stå i fare for å dø, altså både friske og syke (risikopopulasjonen).

\section{Letalitet}

Letalitet er et annet mål på dødelighet. Det angir andelen syke som dør av den sykdommen de er rammet av i løpet av en gitt tid, og er et mål på hvor alvorlig sykdommen er. I nevneren inngår av den grunn bare de som har fått sykdommen.

For både mortalitet og letalitet finner vi i nevneren den befolkning som risikerer å ende opp i telleren (risikopopulasjon). Man kan si at mortaliteten av rabies i Norge er svært lav, det er svært få som dør i forhold til befolkningen som kan bli rammet. Letaliteten av sykdommen er derimot svært høy: mange av dem som blir smittet, dør av sykdommen.
På engelsk kalles letalitet for «case fatality rate». Men i Norge er begrepet letalitet både kortere og like presist. Det er forresten litt pussig at man på engelsk bruker «fatality» i denne sammenhengen - man ville kanskje heller forventet at det skulle hete «case lethality rate», men slik er det ikke. Begrepene fatal og letal kan være besværlige også på norsk (2).

Mens letalitet betegner andelen som dør, kan man snu på flisa og beskrive andelen som overlever. Da snakker man om overlevelsessannsynlighet. Det fremstilles som oftest i et Kaplan-Meier-diagram (fig 1) (3).

Det er stor forskjell på hvor hyppig disse begrepene brukes, også i Tidsskriftet: dødelighet 1221 ganger, mortalitet 646 ganger og letalitet bare 61 ganger (1.11. 2011).

\section{Til slutt}

Epidemiologiske begreper er ikke så enkle. For noen år siden ble det foreslått å bruke befolkningsdødelighet for mortalitet og sykdomsdødelighet for letalitet $(4,5)$. For å lette kommunikasjonen kan det $\mathrm{i}$ hvert fall være klokt å bruke beskrivende termer, f.eks. nye sykdomstilfeller per $100000 \mathrm{inn}$ byggere i stedet for insidensrate (6). Rent

\section{Ramme 1 \\ - Mortalitet $=$ befolkningsdødelighet $=$ hvor stor andel av befolkningen som dør i løpet av en gitt tidsperiode (f.eks. ett år) \\ - Letalitet $=$ sykdomsdødelighet $=$ hvor mange av dem som har fått sykdom- men, som dør av sykdommen i løpet av en gitt tidsperiode (f.eks. ett år) \\ - Dødelighet $=$ fellesbetegnelse for mor- talitet og letalitet}

praktisk er det ofte presist nok å bruke samlebegrepet dødelighet uten å spesifisere om man mener mortalitet eller letalitet.

\section{Erlend Hem}

erlend.hem@medisin.uio.no

Geir W. Jacobsen

Tidsskriftet

Erlend Hem (f. 1970) er dr.med. og assisterende redaktør i Tidsskriftet.

Geir W. Jacobsen (f. 1945) er professor ved Institutt for samfunnsmedisin, Norges teknisknaturvitenskapelige universitet og medisinsk redaktør i Tidsskriftet.

\section{Litteratur}

1. Bakketeig LS, Westin S. Mortalitet versus letalitet. Tidsskr Nor Lægeforen 1994; 114: 3227.

2. Hem E, Jacobsen GW. Fatal eller letal? Tidsskr Nor Legeforen 2011; 131: 980.

3. Næss H, Waje-Andreassen U, Brøgger J et al. Pasienter med akutt hjerneinfarkt innlagt i slagenhet. Tidsskr Nor Legeforen 2011; 131 814-8.

4. Stavem P, Bjerkedal T, Waaler HT. Befolkningsdødelighet og sykdomsdødelighet. Tidsskr Nor Lægeforen 1995; 115: 646

5. Bakketeig LS, Westin S. Tilsvar. Tidsskr Nor Lægeforen 1995; 115: 646.

6. Gedde-Dahl TW. Mortalitet eller befolkningsdødelighet? Tidsskr Nor Lægeforen 1995; 115: 1877 